\title{
Karakteristik dan Preferensi Pengguna Dalam Pemilihan Lokasi Parkir di Koridor Jalan Pemuda, Klaten
}

\section{Characteristic and User Preferences in Choosing Parking Location in Pemuda Road Corridor, Klaten}

\author{
Marcellus Lendra Kusuma ${ }^{\mathrm{a}}$, Djoko Suwandono ${ }^{\mathrm{b}}$ \\ ${ }^{a}$ Departemen Perencanaan Wilayah dan Kota Universitas Diponegoro, Semarang, Indonesia \\ ${ }^{a}$ Departemen Perencanaan Wilayah dan Kota Universitas Diponegoro, Semarang, Indonesia
}

\begin{abstract}
Abstrak
Koridor Jalan Pemuda merupakan koridor utama di Kabupaten Klaten yang memiliki fungsi sebagai kawasan pusat kegiatan (CBD). Berkembangnya sebuah kawasan menyebabkan kebutuhan lahan parkir juga meningkat. Permasalahannya adalah banyak kendaraan yang diparkirkan sembarangan yang menyebabkan hambatan pada jalan dan mengurangi estetika kota. Perlu adanya perencanaan kawasan parkir yang sesuai dengan karakteristik masyarakat disana. Tujuan dari penulisan penelitian ini adalah untuk mengetahui karakteristik dan preferensi pengguna dalam pemilihan lokasi parkir pada koridor Jalan Pemuda Kabupaten Klaten. Pengumpulan data pada penelitian ini menggunakan data primer yang diperoleh dari kuesioner. Target responden dalam penelitian ini adalah semua masyarakat yang memarkir kendaraannya di koridor Jalan Pemuda, yang dibagi menjadi empat zona lokasi serta tiga zona waktu, yaitu pagi, siang dan sore hari. Hasilnya adalah karakteristik pengguna pada pagi hari didominasi keperluan kunjungan yaitu bekerja dengan durasi parkir yang lama (>4 jam), lalu pada siang hari didominasi keperluan kunjungan berbelanja dengan durasi parkir sedang (1-2 jam), serta keperluan kunjungan belanja dan rekreasi dengan durasi parkir sedang (1-2 jam) pada sore hari. Sementara itu analisis preferensi menempatkan variabel keamanan menjadi yang terpenting dalam pemilihan lokasi parkir
\end{abstract}

Kata kunci: Perparkiran; Preferensi Masyarakat; Koridor Jalan

\begin{abstract}
Pemuda road corridor is the main corridor in Klaten Regency which has function as Central Business District (CBD). The growth of an area led to the need for parking space also increased. The problem is that many parked carelessly vehicles that cause roadblocks and reduce the aesthetics of the city. Needs a parking area planning in accordance with the characteristics of the people there. The purpose of this study is to understand the characteristic and preferences of users in choosing of parking location on Pemuda road corridor Klaten Regency. Data collection in this study used primary data obtained from the questionnaire. The respondent's target in this research is all the people who park their vehicles in Pemuda road corridor, which is divided into four zones of location and three time zones; morning, noon and afternoon. The result is characteristics of the user in the morning is dominated by the purpose of visit is to work with a long time parking duration ( $>4$ hours), then in the noon is dominated by the purpose of visit is shopping with medium parking duration (1-2 hours), and shopping and recreation purposes with medium duration parking (1-2 hours) in the afternoon. Meanwhile the preference analysis puts the security variable to be the most important in choosing of parking location.
\end{abstract}

Keyword: Parking; User Preference, Street Corridor

\section{Pendahuluan}

Pertumbuhan sebuah koridor jalan tidak akan lepas dari kegiatan atau aktivitas yang terjadi didalamnya. Koridor Jalan Pemuda di Kabupaten Klaten merupakan koridor utama yang 
menghubungkan 2 kota besar, yaitu Kota Surakarta dengan Yogyakarta yang terus berkembang dengan alasan koridor Jalan Pemuda memiliki fungsi kawasan sebagai kawasan perkantoran serta perdagangan dan jasa. Kawasan dengan padat bangunan sering menimbulkan masalah karena kurang diperhatikan daya dukung serta kemampuan lahan untuk dapat menerima besar kecilnya bangunan yang ada diatasnya. Aktivitas yang terjadi tidak hanya satu macam saja, melainkan ada beberapa aktivitas pendukung, seperti aktivitas perkantoran, pendidikan, komersial serta hunian. Pusat aktivitas koridor dapat berupa pusat perdagangan dan jasa serta perkantoran atau bisnis (Central Business District).

Tingginya populasi penduduk dan kebutuhan mobilitas masyarakat perkotaan yang semakin tinggi berimplikasi pada peningkatan arus transportasi kendaraan pribadi maupun kendaraan umum. Karakteristik kawasan CBD yaitu memiliki bangkitan perjalanan (Azzaki \& Sumandono, 2013). Meningkatnya perjalanan mengakibatkan tingginya kebutuhan akan lahan parkir yang berada di koridor tersebut. Untuk mengatasi permasalahan parkir, diperlukan suatu perancangan dengan memperhatikan kemungkinan yang terjadi atau perkembangan dimasa mendatang. Penataan parkir ini menjadi sangat penting jika terjadi pada kawasan ramai padat aktivitas sehingga membutuhkan lahan parkir untuk menampung kendaraan yang digunakan oleh masyarakat yang beraktivitas (Jurista \& Farida, 2016). Dengan adanya perancangan, akan ada penyelesaian untuk permasalahan parkir yang ada. Perancangan parkir tersebut terdiri dari perancangan parkir sirkulasi dan estetika yang ada di kawasan tersebut. Perancangan ini tentunya harus memperhatikan kondisi eksistingnya sehingga diperlukan karakteristik kawasan yang mempengaruhi parkir. Karakteristik tersebut didapatkan dari pengguna parkir di koridor Jalan Pemuda yang berada di Kabupaten Klaten. Adanya kendaraan yang menggunakan badan jalan sebagai tempat parkir pada ruas Jalan Pemuda, berdampak pada pergerakan yang melewati ruas jalan tersebut. Selain itu, kondisi parkir yang belum tertata, terkesan mengurangi nilai estetika kota. Berdasarkan permasalahan yang telah diuraikan diatas membuktikan bahwa perencanaan kawasan parkir masih belum diperhatikan.

Penting dilakukannya penelitian ini sebagai acuan ataupun rujukan dalam merencanakan kawasan parkir di koridor Jalan Pemuda dengan harapan mengurangi permasalahan yang terjadi akibat parkir antara lain yaitu kemacetan, kecelakaan lalu lintas, maupun merusak estetika kota. Tujuan dari penulisan penelitian ini adalah untuk menilai aktivitas parkir berdasarkan karakteristik masyarakat dan mengidentifikasi pendapat pengguna dalam pemilihan lokasi parkir pada koridor Jalan Pemuda Kabupaten Klaten. Analisis yang dilakukan untuk mendukung penelitian ini yaitu analisis kondisi fisik, analisis karakteristik masyarakat, analisis fungsi dan aktivitas kawasan, serta preferensi masyarakat. Dengan analisis tersebut diharapkan dapat diketahui karakteristik dan preferensi pengguna dalam pemilihan lokasi parkir pada koridor Jalan Pemuda Kabupaten Klaten.

Kondisi parkir di koridor Jalan Pemuda memiliki dua jenis lahan untuk memarkir kendaraan, yaitu parkir yang berada di sisi jalan (on street parking) dan parkir yang berada di luar jalan (off street parking). Untuk parkir on-street, berada dibagian bahu Jalan Pemuda. Pada jalur lambat, parkir diperuntukkan bagi kendaraan kecil seperti motor dan becak. Namun terdapat pula yang parkir berupa truk kecil atau mobil pickup untuk bongkar muat barang, sedangkan pada jalur cepat, disediakan bahu jalan untuk parkir kendaraan roda empat dengan pola parkir sejajar $\left(0^{\circ}\right)$ atau pola parkir parallel. Sementara itu, pada parkir off-street menyebar disepanjang koridor Jalan Pemuda. Pada salah satu pasar modern yang terbesar di Klaten, memiliki taman parkir yang menggunakan sistem parkir off street. Kemudian kantor-kantor perbankan juga menyediakan halaman parkir bagi nasabahnya. Namun terbatasnya halaman parkir yang dimiliki oleh kantor perbankan, hanya bisa menampung parkir untuk kendaraan roda dua saja, sebagian kendaraan roda empat menggunakan sisi jalan untuk parkir. 


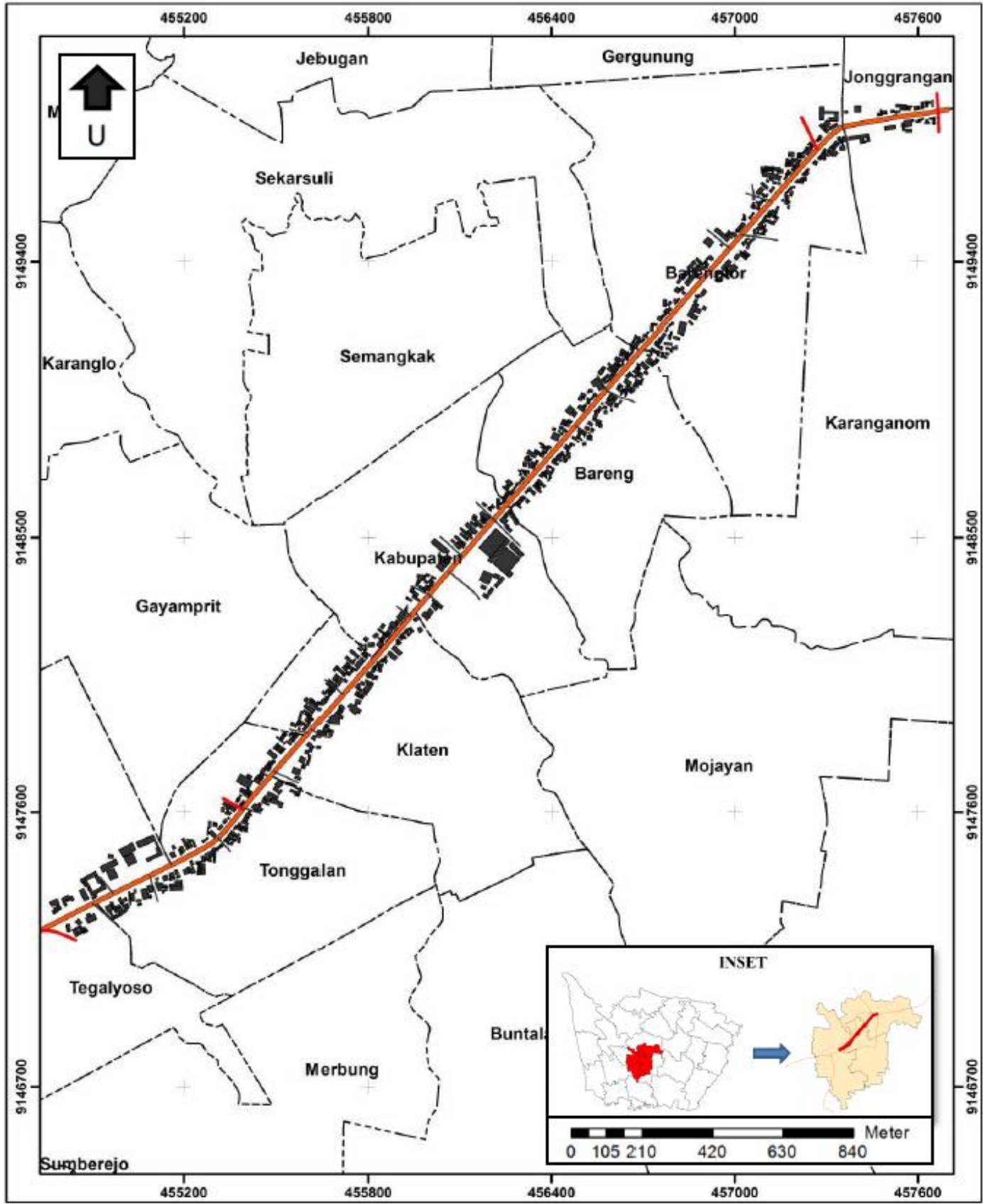

Gambar 1. Peta Koridor Jalan Pemuda Kabupaten Klaten. (Bappeda Kab. Klaten, 2016)

\section{Metode}

Metode yang digunakan adalah analisis deskriptif kuantitatif dengan metode statistik desktiptif. Analisis deskriptif kuantitatif adalah teknik analisis yang digunakan untuk mendeskripsikan hasil analisis, menarik kesimpulan, sesuai dengan kajian teori dan variabel penelitian terhadap hasil survey. Statistik deskriptif adalah metode statistik yang digunakan untuk menganalisis data dengan cara mendeskripsikan atau menggambarkan data yang telah terkumpul sebagaimana adanya (Sugiyono, 2009). Analisis statistik deskriptif pada penelitian ini digunakan untuk mengolah data-data kuesioner mengenai aktivitas dan preferensi pengguna parkir terhadap masing-masing variabel dan mendeskripsikan hasil pengolahan data tersebut sehingga menjadi informasi yang menggambarkan bagaimana aktivitas perparkiran dan preferensi terhadap fasilitas parkir. Penerjemahan data-data kuesioner dalam statistik deskriptif dapat menggunakan tabel, diagram, grafik, dan sebagainya. Hal ini perlu dilakukan agar hasil analisis yang dilakukan dapat dengan lebih mudah dipahami oleh para pembaca. Berikut adalah rincian beberapa identifikasi dan analisis yang akan dilakukan oleh peneliti: 
- Analisis Karakteristik Pengguna Parkir

Analisis karakteristik pengguna parkir bertujuan untuk mendapat gambaran tentang karakteristik pengguna parkir. Terdapat 6 indikator yang digunakan untuk menilai karakteristik pengguna parkir, yaitu keperluan kunjungan, asal pengguna, klasifikasi kendaraan, waktu kedatangan, lama (durasi) parkir, jarak dari lokasi parkir ke tempat kegiatan. Teknik survey yang digunakan adalah survey primer dengan teknik koesioner.

- Analisis Preferensi Pengguna Dalam Pemilihan Lokasi Parkir

Analisis preferensi pemilihan lokasi parkir bertujuan untuk mengetahui pilihan atau faktor utama pengguna dalam memilih lokasi parkir yang nantinya dapat dijadikan prioritas dalam pengembangan kawasan parkir dimasa yang akan datang. Untuk mengetahuinya, akan digunakan metode scoring atau pembobotan yang dibantu dengan skala Likert. Skala Likert digunakan untuk mengkur persepsi/ sikap seseorang terhadap suatu fenomena (Sugiyono, 2009). Tiap variabel akan memiliki bobot sendiri, secara berurutan yaitu $1,2,3,4,5$. Dengan jumlah responden yaitu 92 orang, bobot yang didapatkan pada tiap variabel memiliki minimal 92 poin dan maksimal memiliki 460 poin, dari situ akan diketahui variabel mana yang menjadi alasan atau faktor utama pengguna dalam memilih lokasi parkir.

\section{Transportasi dan Preferensi Masyarakat}

\subsection{Transportasi Perkotaan}

Kegiatan manusia yang berbagai macam ragamnya memerlukan hubungan satu dengan yang lainnya. Untuk dapat menghubungkan satu kegiatan dengan kegiatan lainnya diperlukan suatu alat penghubung. Salah satu alat penghubung yang paling tua umurnya adalah transportasi (Warpani, 1990). Pada kawasan perkotaan, aktivitas yang terpusat menyebabkan berbagai permasalahan pada pusat kota, salah satunya adalah masalah transportasi yang meliputi perjalanan orang ke tempat kerja, berbelanja atau aktivitas lainnya baik menggunakan sepeda, kendaraan bermotor pribadi maupun kendaraan umum sehingga memerlukan tempat parkir. Untuk mengurangi masalah yang terjadi, dibutuhkan langkah pengendalian aktivitas, yaitu berupa pengendalian tempat parkir. Sebab, pengendalian parkir merupakan salah satu kunci dari suksesnya pengendalian lalu lintas di perkotaan. Jaringan jalan di kota-kota Indonesia menghadapi permasalahan transportasi seperti kemacetan lalu lintas yang salah satunya disebabkan oleh arus urbanisasi dan pertumbuhan ekonomi. Ketidaklancaran arus lalu lintas ini menimbulkan masalah-masalah lalu lintas, seperti (Tamin, 2000):

- Kemacetan lalu lintas;

- Tundaan perjalanan;

- Kecelakaan lalu lintas;

- Polusi suara atau kebisingan, dan;

- Kebutuhan parkir.

Pengendalian lalu lintas merupakan masalah yang biasanya terjadi di kota-kota besar, yaitu besarnya arus lalu lintas sudah melampaui batas daya dukung jalan atau lingkungan. Metode yang biasanya digunakan untuk membatasi lalu lintas adalah dengan kebijakan parkir. Perkembangan koridor pada suatu kota juga berpengaruh pada tingkat kebutuhan parkir, perencanaan koridor merupakan suatu pendekatan yang lebih menyeluruh terhadap perencanaan daerah jalan perkotaan (Bishop, 1989).

\subsection{Jalan}

Jalan adalah suatu prasarana perhubungan darat dalam bentuk apapun, meliputi segala bagian jalan termasuk bangunan pelengkap dan perlengkapan yang diperuntukan bagi lalu lintas. Jalan mempunyai peranan penting terutama yang menyangkut perwujudan perkembangan antara daerah yang seimbang dan pemerataan hasil pembangunan serta pemantapan pertahanan dan keamanan nasional dalam mewujudkan pembangunan nasional (UU No. 38 tahun 2004). Setiap jalan yang ada di kota atau daerah memerlukan fasilitas pendukung demi terselenggaranya lalu lintas dan perangkutan. Pemerintah dalam melaksanakan pembangunan, pengelolaan dan pemeliharaan fasilitas pendukung tersebut dapat dilakukan dengan kerjasama oleh swasta. Fasilitas pendukung dalam penyenggaraan lalu lintas di jalan menurut (UU. No.22 tahun 2009) 
adalah: trotoar; jalur sepeda; tempat penyeberangan pejalan kaki; halte; dan/atau fasilitas khusus bagi penyandang cacat dan lansia.

\subsection{Perparkiran}

Pengertian parkir menurut beberapa pakar; parkir adalah tempat pemberhentian kendaraan beberapa saat (Wicaksono, 1989). Parkir adalah tempat memangkalkan/ menempatkan dengan memberhentikan kendaraan angkutan/barang bermotor/tidak bermotor pada suatu tempat dalam jangka waktu tertentu (Warpani, 1990). Parkir adalah keadaan tidak bergerak suatu kendaraan yang bersifat sementara (Pedoman Teknis Penyelenggaraan Fasilitas Parkir Direktur Jendral Perhubungan Darat, 1996). Berdasarkan beberapa pengertian tersebut, maka dapat disimpulkan bahwa parkir adalah tempat kendaraan bermotor/tidak dalam jangka waktu tertentu sesuai kebutuhan pengguna parkir.

Berdasarkan letak/ penempatannya, menutur (Chiara, Joseph de dan Koppelman, 1975), dibagi menjadi dua yaitu parkir ditepi jalan (on-street parking) dan parkir diluar sisi jalan (offstreet parking). adapun mengertian dari keduanya sebagai berikut

a) Parkir ditepi jalan (on-street parking)

Merupakan jenis parkir yang penempatannya disepanjang tepi sisi jalan, dengan ataupun tidak melebarkan sisi jalan itu sendiri bagi fasilitas parkir. Parkir jenis ini sangat menuntungkan bagi pengunjung yang menginginkan parkir dekat dengan tempat tujuan. Tempat parkir seperti ini dapat ditemui di kawasan permukiman yang berkepadatan cukup tinggi serta pada kawasan pusat perdagangan dan perkantoran yang umumnya tidak siap menampung pertambahan dan perkembangan jumlah kendaraan yang parkir. Kerugian dari jenis parkir seperti ini dapat mengurangi kapasitas kendaraan yang mengakibatkan berkurangnya jalur lalu lintas.

b) Parkir diluar sisi jalan (off-street parking)

Termasuk jenis parkir yang penempatannya pada suatu area tertentu diluar sisi jalan. Parkir jenis ini umumnya mempunyai lokasi di pelataran umum yang terbuka maupun tertutup dan memungkinkan orang tidak terpancang pada satu tujuan saja, tetapi dapat pergi ke berbagai tempat yang ada disekitarnya. Jenis parkir ini juga dapat terbatas untuk kegiatan tertentu saja, misalnya parkir di gedung-gedung pemerintah, hotel-hotel dan sebagainya.

\subsection{Karakteristik Masyarakat}

Mengidentifikasi karakter parkir pada suatu kawasan, data yang perlu diamati (McShane,

William R. dan Roess, 1990) adalah:

- Jumlah total kendaraan yang parkir

- Jumlah kendaraan yang parkir tiap interval waktu

- Lama pengamatan tiap interval waktu

- Jumlah ruang parkir yang ada dalam kawasan

- Rata-rata jangka waktu parkir kendaraan

- Angka pergantian parkir kendaraan

- Waktu pelayanan parkir

Sementara itu, menurut (Tamin, 2000) karakteristik parkir dapat dilihat dari:

- Akumulasi Parkir

Akumulasi merupakan suatu informasi mengenai jumlah kendaraan yang berada disuatu lahan parkir dalam selang waktu tertentu;

- Lama Waktu / Durasi Parkir

Lama waktu parkir sangat bergantung dari maksud perjalanan;

- Kapasitas Parkir

Kapasitas parkir merupakan banyaknya kendaraan yang dilayani oleh suatu lahan parkir selama waktu pelayanan;

- Indeks Parkir

Indeks parkir adalah presentase dari akumulasi jumlah kendaraan dalam selang waktu tertentu dibagi dengan ruang parkir. 
Kemudian, faktor-faktor yang mempengaruhi dalam pemilihan lokasi parkir (Teknomo, Kardi dan Hokao, 1997) :

- Availability (Ketersediaan)

- Closeness (Kedekatan)

- Comfortability (Kenyaman)

- Parking Fee (Biaya)

- Security (Keamanan)

- Walking Path Condition (Kondisi jalur pejalan kaki)

\subsection{Preferensi Masyarakat}

Preferensi memiliki arti sesuatu yang lebih diminati, suatu pilihan utama merupakan kebutuhan prioritas dan memberi keuntungan yang lebih baik (Simon \& Schuster Inc, 1996 dalam Subiakto, 2009). Preferensi merupakan suatu hal yang harus didahulukan, dan diutamakan daripada yang lain, prioritas, pilihan, kecenderungan dan yang lebih disukai (Departemen Pendidikan Nasional, 2001 dalam Subiakto, 2009), sedangkan menurut (Wojowasito, 1980 dalam Subiakto, 2009) bahwa preferensi merupakan istilah bahasa Indonesia yang berasal dari bahasa inggris preference yang diartikan sebagai lebih memilih atau lebih suka dalam (Subiakto, 2009).

Preferensi Masyarakat berasal dari adanya sensasi yang merupakan proses masuknya stimulus ke dalam panca indera. Proses masuknya stimulus ke dalam panca indera nantinya akan membuat otak menerjemahkan stimulus tersebut. Kemampuan otak menerjemahakan stimulus atau menginterpretasi stimulus inilah yang sering disebut dengan persepsi (Sugihartono dkk, 2007). Nantinya interpretasi stimulus ini nantinya akan memacu terbangunnya reaksi ataupun respon dari individu tersebut. Reaksi ataupun respon inilah tersebut dapat berupa pilihan reaksi dari individu ataupun kelompok yang mengalami hal tersebut atau yang sering disebut dengan preferensi.

\section{Karakteristik dan Preferensi Pengguna}

\subsection{Karaktersitik Pengguna Parkir}

Karakteristik pengguna parkir dapat dilihat dari 7 indikator yang dapat digunakan, yaitu usia, pekerjaan, asal pengguna, klasifikasi kendaraan, keperluan kunjungan, lama (durasi) parkir, jarak dari lokasi parkir ke tempat kegiatan.

a) Usia merupakan salah satu aspek dalam pemilihan keputusan. Grafik lingkaran dibawah ini menunjukan bahwa mayoritas pengguna parkir di Jalan Pemuda Kabupaten Klaten berada dalam usia produktif yaitu sebanyak 91 dari 92 responden dengan presentase $98,9 \%$. Sementara itu, hanya terdapat 1 responden yang masuk dalam kelompok usia non produktif. Sebagai kawasan pusat pemerintahan dan perkantoran membuat koridor Jalan pemuda tidak pernah sepi, berbagai macam aktivitas dilakukan dan sebagian besar dari mereka merupakan kelompok usia produktif. Berikut adalah diagram persentase usia pengguna parkir di koridor Jalan Pemuda.

b) Dikelompokan berdasarkan pekerjaannya, pengguna parkir di koridor Jalan Pemuda bisa dikategorikan heterogen, karena $34 \%$ atau sebanyak 31 responden adalah pekerjaan lain-lain. Lalu berikutnya sebanyak $18 \%$ atau 17 responden pengguna parkir merupakan mahasiswa, sebagaian besar dari mereka berbelanja di toko retail dan ada sebagian dari mereka yang sedang magang di institusi pemerintahan. Berikutnya ada parah buruh harian dan kuli sebanyak $12 \%$ atau 11 responden. Berikutnya terdapat $11 \%$ atau 10 responden yang bekerja sebagai pegawai swasta, karena memang disepanjang Jalan Pemuda banyak terdapat perkantoran seperti perbankan. Lalu secara perturut terut yaitu pelajar sebanyak $10 \%$, wirausaha sebanyak $9 \%$ dan pegawai negeri sebesar 6\%. Berikut adalah diagram persentase pengguna parkir berdasarkan pekerjaan di koridor Jalan Pemuda.

c) Ditinjau dari asalnya, pengguna parkir pada koridor Jalan Pemuda didominasi oleh pengguna yang berasal dari dalam pekotaan Klaten yaitu sebesar $62 \%$ atau 57 responden, sedangkan lebih dari sepertiganya yaitu $38 \%$ atau 35 responden berasal dari perkotaan Klaten. yang termasuk dalam perkotaan Klaten adalah Kecamatan 
Klaten Selatan, Tengah dan Utara (Perda RTRW Kab Klaten tahun 2011-2031 Bab 3 Pasal 9). Walau tetap didominasi oleh penggunjung dalam kota, namun angka sepertiga lebih responden yang berasal dari luar perkotaan menunjukan koridor Jalan Pemuda mempunya tarikan yang kuat sebagai pusat kegiatan di Kabupatenm Klaten. Berikut adalah diagram persentase asal pengnjung koridor Jalan Pemuda.

d) Berdasarkan klasifikasi kendaraan yang menjadi responden, terdapat $81 \%$ atau 75 responden yang menggunakan kendaraan sepeda motor untuk beraktivitas di koridor Jalan Pemuda. Lalu sebesar 10\% atau 9 responden menggunakan mobil barang dan terdapat $9 \%$ atau 8 responden yang menggunakan mobil penumpang. Dari data diatas dapat diketahui bahwa mayoritas pengguna parkir di koridor Jalan Pemuda adalah kendaran roda dua, selain mudah untuk dijangkau, kepraktisan menjadi hal yang menyebabkan kendaraan roda dua yang dijadikan moda transportasi favorit. Berikut adalah diagram persentas moda/kendaraan pengguna parkir.

e) Dilihat dari keperluan kunjungan di koridor Jalan Pemuda, terdapat $42 \%$ atau 39 responden berbelanja, $20 \%$ atau 18 responden memiliki keperluan lain-lain, $18 \%$ atau 17 responden bekerja, 13\% atau 12 responden rekreasi dan $7 \%$ atau 6 responden keperluan sekolah. Dapat dilihat bahwa alasan bekunjung atau parkir di koridor Jalan Pemuda didominasi oleh masyarakat yang berbelanja. Ditadak heran dikarenakan disepanjang Jalan Pemuda terdapat bayak sekali toko retail dan ruko-ruko mulai yang kecil hingga toko retail besar/supermarket. Berikut adalah diagram persentase keperluan kunjungan pengguna parkir di koridor Jalan Pemuda.

f) Berdasarkan durasi parkir di koridor Jalan Pemuda, terdapat sebesar $45 \%$ atau 41 responden yang memiliki durasi parkir 1-2 jam. Selanjutnya terdapat $22 \%$ atau 20 responden dengan durasi parkir 2-4 jam, lalu terdapat $17 \%$ atau 16 responden dengan durasi parkir kurang dari 1 jam dan terdapat $16 \%$ atau 15 responden dengan durasi parkir lebih dari 4 jam. Bisa diketahui bahwa mayoritas pengguna parkir di koridor Jalan Pemuda membutuhkan durasi pendek hingga menengah dalam beraktivitas atau melakukan kegiatan di Jalan Pemuda. Berikut adalah diagram persentase durasi parkir di koridor Jalan Pemuda.

g) Berdasarkan jarak dari lokasi parkir ke tempat kegiatannya di koridor Jalan Pemuda, terdapat $70 \%$ atau 64 responden dengan jarak dari tempat parkir kurang dari 50 meter ke lokasi kegiatan. Selanjutnya terdapat sebesar $14 \%$ atau 13 responden dengan jarak 50-100 meter, lalu terdapat $11 \%$ atau 10 responden dengan jarak 100-200 meter dan yang terakhir terdapat 5\% atau 5 responden yang memiliki jarak lebih dari 200 meter dari lokasi kegiatan. Dari data diatas dapat diketahui bahwa mayoritas pengguna parkir di koridor Jalan Pemuda memiliki jarak yang pendek yaitu kurang dari 50 meter dari tempat mereka parkir ke tempat yang mereka tuju untuk melakukan aktivitas. Berikut adalah diagram persentase jarak tempat parkir ke lokasi kegiatan di koridor Jalan Pemuda.

Sementara itu, bila dilihat dari waktu berkunjungnya yaitu pada pagi hari, siang hari dan sore hari, memiliki karakteristik yang berbeda. Pada pagi hari, didomeniasi oleh pegawai negeri, pegawai swasta dan pelajar dengan total persentase sebesar $46,5 \%$, asal pengunjung mayoritas adalah berasal dari dalam kota Klaten, berdasarkan keperluan kunjungannya, didominasi keperluan kunjungan untuk bekerja, durasi parkir dalam kategori lama yaitu $>4$ jam. Pada siang hari memiliki karakterisik yang didominasi dengan keperluan kunjungan berbelanja dengan persentase $46,9 \%$, asal pengunjung seimbang yaitu 50\% dari dalam kota Klaten dan 50\% dari luar kota Klaten, durasi parkir sedang yaitu 1-2 jam. Terakhir pada sore hari, didominasi oleh mahasiswa, buruh dan pelajar, asal pengunjung mayoritas dari dalam kota Klaten, memiliki keperluan kunjungan yaitu berbelanja dan rekreasi dengan durasi parkir sedang yaitu 1-2 jam. 
Preferensi memiliki arti sesuatu yang lebih diminati, suatu pilihan utama, merupakan kebutuhan prioritas dan memberi kenutnungan yang lebih baik (Simon \& Schuster Inc, 1996 dalam Subiakto, 2009). Preferensi pemilihan lokasi parkir digunakan untuk mengetahui pilihan atau faktor utama pengguna dalam memilih lokasi parkir yang nantinya dapat dijadikan prioritas dalam pengembangan kawasan parkir dimasa yang akan datang. Terdapat 6 variabel pemilihan lokasi parkir yaitu; availability (ketersediaan), closeness (kedekatan), comfortability (kenyaman), parking fee (biaya parkir), security (keamanan) dan walking path condition (kondisi jalur pejalan kaki) (Teknomo, Kardi dan Hokao, 1997). Setelah dilakukan pembobotan atau skoring pada tiap variabel, didapati hasil bahwa variabel keamanan menjadi variabel terpenting dalam pemilihan lokasi parkir di koridor Jalan Pemuda. Urutan kedua adalah variabel kenyamanan dalam berparkir.

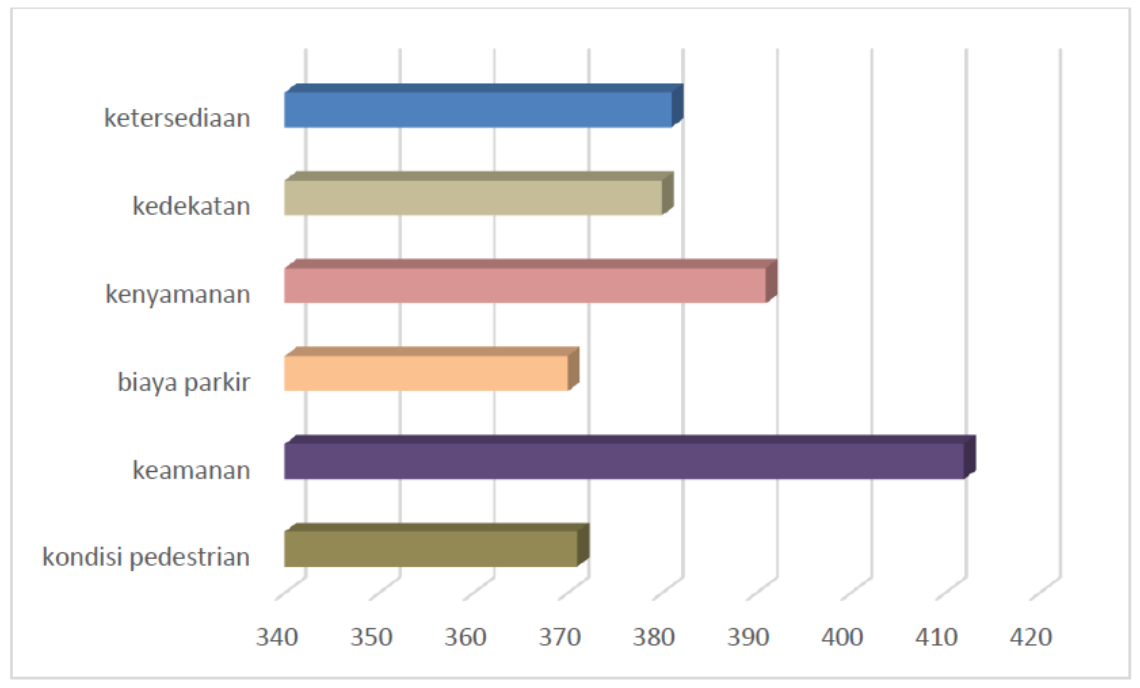

Gambar 2. Grafik Preferensi Pemilihan Lokasi Parkir. (Penyusun, 2018)

\section{Kesimpulan}

Berdasarkan hasil penelitian yang telah dilakukan mengenai kondisi fisik, karakteristik pengguna parkir, fungsi kawasan dan jenis aktivitas serta preferensi pengguna dalam pemilihan lokasi parkir di koridor Jalan Pemuda Klaten, didapatkan beberapa kesimpulan sebagai berikut:

- Dilihat dari karakteristik pengguna parkir pada koridor Jalan Pemuda, mayoritas usia yang beraktivitas parkir masuk dalam kelompok usia produktif dengan persentase sebesar 98,9\%. Berdasarkan pekerjaannya, didominasi oleh lain-lain yaitu sebesar 34\%, ini menunjukan bahwa pekerjaan pengguna parkir koridor Jalan Pemuda adalah heterogen. Lalu dilihat dari asal pengunjung atau pengguna parkir, didapati mayoritas adalah berasal dari perkotaan Klaten yaitu sebesar $62 \%$. Ditinjau dari moda kendaraan yang dipakai responden, kendaraan motorlah yang mayoritas digunakan dengan persentase sebesar $81 \%$ dari 92 responden. Berikutnya dilihat dari keperluan kunjungan, didominasi oleh keperluan berbelanja dengan persentase yaitu $42 \%$. Lalu dilihat dari durasi parkirnya, biasanya pengguna parkir memarkirkan selama 1 sampai 2 jam kendaraannya dengan persentase $45 \%$. Serta yang terakhir adalah jarak dari lokasi parkir ke tempat kegiatan, mayoritas memarkirkan dengan jarak yang dekat yaitu kurang dari 50 meter dengan persentase $70 \%$.

- Karakteristik pengguna parkir di koridor Jalan Pemuda dipengaruhi oleh waktu berkunjung. Pada pagi hari, didomeniasi oleh pegawai negeri, pegawai swasta dan pelajar dengan total persentase sebesar $46,5 \%$, asal pengunjung mayoritas adalah berasal dari dalam kota Klaten, berdasarkan keperluan kunjungannya, didominasi keperluan kunjungan untuk bekerja, durasi parkir dalam kategori lama yaitu $>4$ jam. Pada siang hari memiliki karakterisik yang didominasi dengan keperluan kunjungan berbelanja dengan persentase $46,9 \%$, asal pengunjung seimbang yaitu 50\% dari dalam kota Klaten dan 50\% dari luar kota Klaten, durasi parkir sedang yaitu 1-2 jam. Terakhir pada sore hari, didominasi oleh 
mahasiswa, buruh dan pelajar, asal pengunjung mayoritas dari dalam kota Klaten, memiliki keperluan kunjungan yaitu berbelanja dan rekreasi dengan durasi parkir sedang yaitu 1-2 jam.

- Hasil analisis preferensi pemilihan lokasi parkir yang terdiri dari 6 variabel yaitu; availability (ketersediaan), closeness (kedekatan), comfortability (kenyaman), parking fee (biaya parkir), security (keamanan) dan walking path condition (kondisi jalur pejalan kaki) (Teknomo, 1997). Survey yang dilakukan dengan penyebaran koesioner dengan total 92 responden, menempatkan variabel keamanan menjadi yang terpenting dengan hasil skoring sebesar 412. Lalu urutan kedua adalah variabel kenyamanan dalam berparkir dengan total skoring 391. Variabel dengan hasil skoring terendah adalah variabel biaya parkir yaitu hanya menghasilkan 370 poin. Ini dikarenakan sepanjang koridor Jalan Pemuda memilki biaya parkir yang sama.

- Variabel keamanan adalah yang terpenting berdasarkan preferensi pengguna, untuk itu pemerintah Kabupaten Klaten harus lebih memperhatikan hal tersebut. Aman bukan hanya kendaraannya, namun juga pengguna/ pengunjung parkirnya, karena pola parkir di koridor Jalan Pemuda adalah on street parking yang memang lebih rawan kecelakaan.

\section{Referensi}

Azzaki, M. R., \& Sumandono, D. (2013). Persepsi Masyarakat Terhadap Aktivitas Ruang Terbuka Publik di Lapangan Pancasila Simpang Lima, Semarang. Jurnal Ruang, 1(2), 231-240.

Bishop, K. R. (1989). Designing Urban Corridors. Washington D.C: American Planning Association.

Chiara, Joseph de dan Koppelman, L. E. (1975). Standar Perencanaan Tapak. Jakarta: Erlangga.

Jurista, A., \& Farida, I. (2016). Penataan dan Penanganan Parkir pada Badan Jalan Sepanjang Ruas Jalan Cimanuk Kabupaten Garut. Jurnal Konstruksi, 14(1), 101-112.

McShane, William R. dan Roess, R. P. (1990). Traffic Engineering. New Jersey: Prentice-Hall.

Subiakto. (2009). Preferensi Pengguna dan Penyedia Jasa Terhadap Sistem Jaringan Transportasi Jalan (JTJ) yang Mendukung Pelabuhan di Kabupaten Belitung. Universitas Diponegoro.

Sugihartono dkk. (2007). Psikologi Pendidikan. Yogyakarta: UNY Press.

Sugiyono. (2009). Metode Penelitian Kuantitatif dan Kualitatif. Bandung: Alfabeta.

Tamin, O. . (2000). Perencanaan dan Pemodelan Transportasi. Bandung: Penerbit ITB.

Teknomo, Kardi dan Hokao, K. (1997). Parking Behavior in Central Business District. A Study Case of Surabaya, Indonesia. Jurnal of the EASTS, Volume 2(No 2).

Warpani, S. (1990). Merencanakan Sistem Perangkutan. Bandung: Penerbit ITB.

Wicaksono, Y. I. (1989). Analisis Kapasitas Parkir yang Optimal dan Penentuan Lay Out Bangunan Parkir yang Cokok. Institut Teknologi Bandung. 